\title{
Off-Pump Myocardial Revascularization from the Beginning till Now
}

\author{
Enio Buffolo* \\ Department of Cardiovascular Surgery, Federal University of Brazil - Paulista School of Medicine, Brazil
}

${ }^{\star}$ Corresponding author: Enio Buffolo, Full Professor, Department of Cardiovascular Surgery, Federal University of Brazil - Paulista School of Medicine, Brazil; Email: buffol.o@terra.com.br

Received: October 31, 2018; Accepted: November 14, 2018; Published: November 22, 2018, 2018;

\section{Editorial}

Surgical myocardial revascularization was introduced in the cardiovascular surgical practice late, just after two decades of experience in congenital heart disease and valvular dysfunctions. The landmark of direct myocardial revascularization was the possibility to access the coronary arteries through coronary angiography developed by Mason Jones in Cleveland Clinic in early sixties [1].

The possibility to identify the presence and severity of coronary obstructions was the birth of modern coronary surgery and more than this, to evaluate and select really effective surgical techniques.

Of several indirect surgical procedures made in the past only the Vineberg technique showed some efficiency [2].

The modern era of direct myocardial revascularization started with the saphenous vein bypass grafts, with massive information coming mainly from Cleveland Clinic regarding diagnosis, selection of patients and technical challenges [3]. Nevertheless, Garret utilized years before a bypass graft instead of endarterectomy in 1962 and published a successful follow-up in 1973. It is important to remind that at that time he didn't have information of cinecoronarygraphy and did this option during a valve operation [4].

Although coronary arteries are located on the surface of the heart and it is not necessary to open cardiac chambers, surgeons started to use cardiopulmonary bypass to make the graft anastomosis due to development of myocardial protection methods, familiarity with extracorporeal circuit and mainly due to perform a difficult anastomosis in a beating field.

Nevertheless, the idea to make a coronary artery anastomosis in a beating heart was applied before the concept of doing a saphenous vein graft bypass under extracorporeal circulation and cardiac arrest.

Goetz et al 1961 [5] did a direct myocardial revascularization utilizing the mammary artery and mechanical suture with tantalum ring.

Vasilii Kolesov and Potashov [6,7] published in Russia (1965) and later in United States (1967) their experience with mammary artery to left anterior descending coronary artery in a beating heart through a left thoracotomy and in few cases with mechanical suture. It is interesting to observe that he didn't have informations about the coronary arteries and made the operation only in clinical basis.
Years later Trapp \& Bisarya [8] in Canada and in the same year Ankeney [9] in Western Reserve - Cleveland independently reported the first series of patients with acceptable results. This alternative of myocardial revascularization did not have acceptance due to technical difficulties and the concept that it was not possible to occlude a coronary artery even for a few minutes without causing a myocardial infarction. Due to this fact complicated distal perfusion devices were necessary introducing more difficulties to perform coronary anastomosis.

Only years later Buffolo et al [10] and independently Benetti [11] published a consecutive series of patients with saphenous or mammary artery grafts to left anterior descending, diagonal and right coronary arteries, calling attention to feasibly and safety of this alternative of myocardial revascularization. Technical maneuvers were described to facilitate anastomosis as position of the table, anesthesia expertise and utilization of pharmacological "stabilizers" like verapamil to reduce heart rate, oxygen consumption and arterial pressure.

During the next decade some papers tried to demonstrate the advantages of myocardial revascularization without pump, but did not have wide acceptance by local and international community [12-18].

Despite the evidence of the feasibility with good results, the confort to perform a conventional coronary artery bypass in an arrested heart and the concerns about the quality of anastomosis led to only isolated experiences for many years, and sometimes with strong criticisms in editorials like: "Look ma no hands!" or "myocardial revascularization without pump, a benefit or a risk for the patient".

The development and persistence in performing off-pump coronary operation by pioneer groups culminated with the concept proposed by Benetti [19] to make a mammary-artery-LAD anastomosis in a beating heart through a mini-left thoracotomy. This idea was presented in a meeting in Rome in 1994 and received the name of MIDCAB (Minimally Invasive Direct Coronary Artery Bypass). The clinical experience was disseminated all around the world by Benetti and popularized by Calafiore et al [20], among others, with the name of "Last operation" (left anterior small thoracotomy).

This idea was strongly attractive and was in our opinion the key to the interest in beating heart surgery. Many groups started to learn how to operate without pump and discovered that was really possible to achieve good quality anastomosis even more, utilizing sternotomy. 
Curiously in 1982, we collected only 5 direct publications in offpump coronary surgery, in 1992,18 and in 1998 an explosion of 18.423 papers in the subject.

With the widespread application of beating heart coronary surgery many important contributions were made like the concept of hybrid approach and the use of stabilizers [21-23].

In the hybrid approach, we use a mammary-artery-left anterior descending anastomosis (LAD) with minimal left thoracotomy (MIDCAB) and before or after, percutaneous angioplasty to other coronary arteries combining the five star treatment of the LAD with a minimally invasive treatment of multivessel coronary artery disease [24-26].

The stabilizers by compression or suction like OCTOPUS ${ }^{\circledR}$ facilitate the anastomosis making a regional "cardiac arrest". It can be used with devices like "STARFISH" ${ }^{\circledR}$ that put the "apex cordis" up to permit visibility of marginal branches of circumflex artery. The use of the stabilizers was very important to get better quality anastomosis and now they are essential in off pump coronary surgery.

In the following decade, we can observe a lot of contributions and randomized controlled trials comparing off-pump and on-pump surgery regarding mortality, morbidity, inflammatory response, patency rates, stroke, blood transfusion, costs, results in high risk patients among others [27-32].

Off-pump coronary surgery was studied under various aspects: advantages and criticisms and opinion makers like Thomas Salerno, Michael Mack, David Taggart, R. Ascione, Gianni Angelini, John Puskas, Antonio Calafiore [33-39] among others established the main concepts, advantages and disadvantages of this alternative of myocardial revascularization.

The different results regarding patency rates and benefits of the offpump technique in our opinion is mainly due to improper training, selection of cases and surgical skills.

Although some groups are now performing $90 \%$ or even $100 \%$ of the operations off-pump, we believe that is difficult to achieve a $100 \%$ application of the technique. In our experience, patients with hypertrophic left ventricles, diffuse athermanous coronary arteries that sometimes need endarterectomy intramyocardial coronary arteries among others need the conventional approach, and the key to avoid unacceptable conversion rates is the proper preoperative selection of patients.

In retrospective analysis of our experience, we think that off-pump myocardial revascularization have strong evidences of advantages regarding reduction in mortality rates, reduction in stroke, lesser major postoperative complications, shorter hospital stay and lower costs. The controversies that we observe in the literature regarding mortality and morbidity are mainly due to excess of enthusiasm trying to apply the technique to all patients, untrained surgeons and selection of patients.

It is very difficult to demonstrate advantages in low risk patients [40]. The differences appears in patients with co-morbidities; worse the patient, better the outcome.
Recent large international randomized trials did show advantages of off-pump coronary surgery compared with conventional revascularization for high risk patients with important co-morbidities like previous CVA, renal insufficiency, pulmonary insufficiency or porcelain aorta. Off-pump surgery in the hands of well trained teams offers a reduced risk regarding mortality and mobility [41-43]

In recent years it was demonstrated that it is possible to perform myocardial revascularization using a robotic system with closed chest in a selected group of patients (TECAB) Totally Endoscopic Coronary Artery Bypass.

This technique using port access and robotics represents the maximum application of a minimally invasive concept using the technology of the new millennium and the applicability and results will be analysed in the next years.

Comparative studies between off-pump coronary surgery and angioplasties will be necessary to stablish new strategies in the management of coronary artery disease because the parameters we have now compares conventional surgery and percutaneous intervention in the majority of randomized controlled trials.

In summary, in our long and large experience with CABG without $\mathrm{CPB}$, the indications for operation with this method has been identified; the method can be used in approximately $25 \%$ of patients undergoing coronary revascularization. Arterial conduits can be used, and the patency rate is similar to that of conventional techniques. The mortality rate is acceptably low, and complication rates were lower compared with conventional techniques. In selected cases, the procedure is cost-effective due to lower use of hospital resources in the operating room, intensive care unit, and ward. The continuing use of this technique of coronary artery surgery is therefore justified.

\section{References}

1. Sones FM Jr, Shirey EK (1962) Cine coronary arteriography. Mod Concepts Cardiovasc Dis 31: 735-738. [crossref]

2. Vineberg AM (1946) Development of an anastomosis between the coronary vessels and a transplanted internal mammary artery. Can Med Assoc J 55: 117-119.

3. Favaloro RG (1968) Saphenous vein autograft replacement of severe segmental coronary artery occlusion: operative technique. Ann Thorac Surg Apr;5: 334-339.

4. Garrett HE, Dennis EW, DeBakey ME (1996) Aortocoronary bypass with saphenous vein graft. Seven-year follow-up. 1973. JAMA 276: 1519-1520. [crossref]

5. Goetz RH, Rohman M, Haller JD, et al. (1961) Internal mammary-coronary artery anastomosis. A nonsuture method employing tantalum rings. J Thorac Cardiovasc Surgm41: 378-386

6. Kolesov VI, Potashov LV (1965) [Surgery of coronary arteries]. Eksp Khir Anesteziol 10: 3-8. [crossref]

7. Kolesov VI (1967) Mammary artery-coronary artery anastomosis as method of treatment for angina pectoris. J Thorac Cardiovasc Surg 54: 535-544

8. Trapp WG, Bisarya R (1975) Placement of coronary artery bypass graft without pump oxygenator. Ann Thorac Surg 19: 1-9. [crossref]

9. Ankeney JL (1975) Editorial: To use or not to use the pump oxygenator in coronary bypass operations. Ann Thorac Surg 19: 108-109. [crossref]

10. Buffolo E, Andrade JCS, Succi JF, et al (1982) Revascularização direta do miocárdio sem circulação extracorpórea. descrição da técnica e resultados iniciais. Arq Bras Cardiol 38: 365-373

11. Benetti FJ (1985) Direct coronary surgery with saphenous vein bypass without either cardiopulmonary bypass or cardiac arrest $J$ Cardiovasc Surg (Torino) 26 : 217-22.

12. Buffolo E, Andrade JC, Succi J, et al (1985) Direct myocardial revascularization without cardiopulmonary bypass. Thorac Cardiovasc Surg 33: 26-29 
13. Buffolo E, Andrade JC, Branco JN, et al (1990) "Myocardial revascularization without extracorporeal circulation. seven-year experience in 593 cases.".Eur $J$ Cardiothorac Surg 4: 504-507

14. Buffolo E, De Andrade CS, Branco JN, et al (1996) Coronary artery bypass grafting without cardiopulmonary bypass. Ann Thorac Surg 61: 63-66

15. Archer R, Ott DA, Parravicini R, Cooley DA, Reul GJ, et al. (1984) Coronary artery revascularization without cardiopulmonary bypass. Tex Heart Inst $J$ 11: 52-57. [crossref]

16. Laborde F, Abdelmequid I, Piwnica A (1989) Aortocoronary bypass without extracorporeal circulation: why and when? Eur J Cardiothorac Surg 3: 152-154

17. Rivetti LA, Gandra SM (1997) Initial experience using an intraluminal shunt during revascularization of the beating heart. Ann Thorac Surg 63: 1742-1747

18. Lima RC, Soares M A, Lobo FJG, et al (2003) Resultados cirúrgicos na revascularização do miocárdio sem circulação extracorpórea. analise de 3.410 pacientes. Rev. Bras. Cir. Cardiovascular18: 261-267

19. Benetti FJ, Ballester C, Sani G, Doonstra P, Grandjean J (1995) Video assisted coronary bypass surgery. J Card Surg 10: 620-625. [crossref]

20. Calafiore AM, Giammarco GD, Teodori G, et al (1996) Left anterior descending coronary artery grafting via left anterior small thoracotomy without cardiopulmonary bypass. Ann Thorac Surg 61: 1658-1663

21. Borst C, Jansen EW, Tulleken CA, et al (1996) Coronary artery bypass grafting without cardiopulmonary bypass and without interruption of native coronary flow using a novel anastomosis site restraining device ("octopus") $J$ Am Coll Cardiol. 27: $1356-1364$

22. Izzat MB, Yim AP (1997) Cardiac stabilizer for minimally invasive direct coronary artery bypass. Ann Thorac Surg 64: 570-571. [crossref]

23. Shennib H, Lee AG, Akin J (1997) Safe and effective method of stabilization for coronary artery bypass grafting on the beating heart. Ann Thorac Surg 63: 988-992. [crossref]

24. Angelini GD, Wilde P. Salerno T. A. et al (1966) Integrated left small thoracitomy and angioplasty for multivessel coronary artery revascularization Lancet 347 : $757-758$

25. Wittwer T, Cremer J, Boonstra P, Grandjean J, Mariani M, et al. (2000) Myocardial "hybrid" revascularisation with minimally invasive direct coronary artery bypass grafting combined with coronary angioplasty: preliminary results of a multicentre study. Heart 83: 58-63. [crossref]

26. Riess FC, Bader R, Kremer P, Kühn C, Kormann J, et al. (2002) Coronary hybrid revascularization from January 1997 to January 2001: a clinical follow-up. Ann Thorac Surg 73: 1849-1855. [crossref]

27. Cleveland JC Jr, Shroyer AL, Chen AY, et al (2001) Off-pump coronary artery bypass grafting decreases risk-adjusted mortality and morbidity. Ann Thorac Surg 72: $1282-1288$.

28. Al-Ruzzeh S, Ambler G, Asimakopoulos G, et al (2003) Off-pump coronary artery bypass (OPCAB) surgery reduces risk-stratified morbidity and mortality: a United Kingdom multi-center comparative analysis of early clinical outcome. Circulation 108: $115-120$

29. Sergeant P, Wouters P, Meyns B, et al (2004) Opcab versus early mortality and morbidity: an issue between clinical relevance and statistical significance. Eur $J$ Cardiothorac Surg 25: 779-785

30. Brasil LA, Gomes WJ, Salomão R, Buffolo E (1998) Inflammatory response after myocardial revascularization with or without cardiopulmonary bypass. Ann Thorac Surg 66: 56-59

31. Ascione R, Lloyd CT, Underwood MJ, et al (2000) Inflammatory response after coronary revascularization with or without cardiopulmonary bypass. Ann Thorac Surg 69: 1198-1204

32. Edmunds LH Jr (1998) Inflammatory response to cardiopulmonary bypass. Ann Thorac Surg 66: 12-16. [crossref]

33. Mack MJ (2000) Beating heart surgery for coronary revascularization: is it the most important development since the introduction of heart lung machine? Ann Thorac Surg 70: 1779-1781

34. Salerno T, Ricci M, Karamanoukian HL et al (2001) Beating heart coronary artery surgery" Futura Publishing Company Inc 2001

35. Mack MJ, Pfister A, Bachand D, et al (2004) Comparison of coronary bypass surgery with and without cardiopulmonary bypass in patients with multivessel disease. J Thorac Cardiovasc Surg 127(1): 167-173

36. Calafiore AM, Di Mauro M, Canosa C, et al (2003) Myocardial revascularization with and without cardiopulmonary bypass: advantages, disadvantages and similarities." Eur J Cardiothorac Surg 24: 953-960

37. Angelini GD, Taylor FC, Reeves BC, Ascione R (2002) Early and midterm outcome after off-pump and on-pump surgery in Beating Heart Against Cardioplegic Arrest Studies (BHACAS 1 and 2): a pooled analysis of two randomised controlled trials. Lancet 359: 1194-1199. [crossref]
38. Puskas JD, Williams WH, Duke PG, et al (2003) Off-pump coronary artery bypass grafting provides complete revascularization with reduced myocardial injury, transfusion requirements, and length of stay: a prospective randomized comparison of two hundred unselected patients undergoing off-pump versus conventional coronary artery bypass grafting. J Thorac Cardiovasc Surg 125: 797-808

39. Taggart DP1, Westaby S (2001) Neurological and cognitive disorders after coronary artery bypass grafting. Curr Opin Cardiol 16: 271-276. [crossref]

40. Gerola LR, Buffolo E, Jasbik W, Botelho B, Bosco J, et al. (2004) Off-pump versus on-pump myocardial revascularization in low-risk patients with one or two vessel disease: perioperative results in a multicenter randomized controlled trial. Ann Thorac Surg 77: 569-573. [crossref]

41. Diegeler A, Börgermann J, Kappert U, Breuer M, Böning A, et al. (2013) Off-pump versus on-pump coronary-artery bypass grafting in elderly patients. $N$ Engl $\mathrm{J}$ Med 368: 1189-1198. [crossref]

42. Lamy A, Devereaux PJ, Prabhakaran D, Taggart DP, Hu S, et al. (2013) Effects of off-pump and on-pump coronary-artery bypass grafting at 1 year. $N$ Engl $J$ Med 368: 1179-1188. [crossref]

43. Sá MP, Ferraz PE, Escobar RR, Martins WN, Lustosa PC, et al. (2012) Off-pump versus on-pump coronary artery bypass surgery: meta-analysis and meta-regression of 13,524 patients from randomized trials. Rev Bras Cir Cardiovasc 27: 631-641. [crossref]

\section{Citation:}

Enio Buffolo (2018) Off-Pump Myocardial Revascularization from the Beginning till Now. Cardiac Sci Res $J$ Volume 1(1): 1-3. 